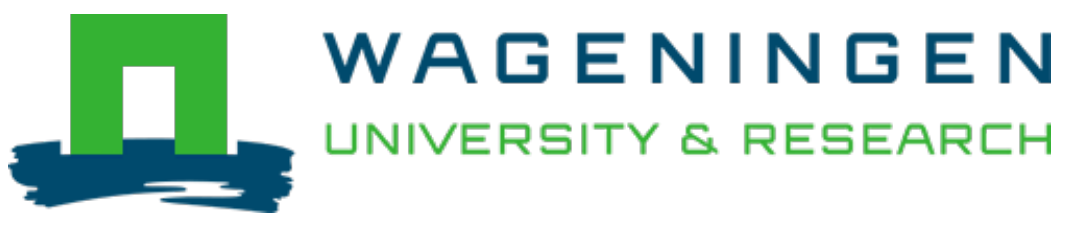

\title{
Ecology of accelerated natural lactic fermentation of sorghum-based infant food formulas.
}

International Journal of Food Microbiology

Nout, M.J.R.

https://doi.org/10.1016/0168-1605(91)90072-w

This publication is made publicly available in the institutional repository of Wageningen University and Research, under the terms of article $25 \mathrm{fa}$ of the Dutch Copyright Act, also known as the Amendment Taverne. This has been done with explicit consent by the author.

Article 25 fa states that the author of a short scientific work funded either wholly or partially by Dutch public funds is entitled to make that work publicly available for no consideration following a reasonable period of time after the work was first published, provided that clear reference is made to the source of the first publication of the work.

This publication is distributed under The Association of Universities in the Netherlands (VSNU) 'Article $25 \mathrm{fa}$ implementation' project. In this project research outputs of researchers employed by Dutch Universities that comply with the legal requirements of Article $25 \mathrm{fa}$ of the Dutch Copyright Act are distributed online and free of cost or other barriers in institutional repositories. Research outputs are distributed six months after their first online publication in the original published version and with proper attribution to the source of the original publication.

You are permitted to download and use the publication for personal purposes. All rights remain with the author(s) and / or copyright owner(s) of this work. Any use of the publication or parts of it other than authorised under article $25 \mathrm{fa}$ of the Dutch Copyright act is prohibited. Wageningen University \& Research and the author(s) of this publication shall not be held responsible or liable for any damages resulting from your (re)use of this publication.

For questions regarding the public availability of this publication please contact openscience.library@wur.nl 


\title{
Ecology of accelerated natural lactic fermentation of sorghum-based infant food formulas
}

\author{
M.J.R. Nout \\ Depariment of Food Science, Agricultural University, Wageningen. The Netherlands
}

(Received 18 June 1990; accepted 25 October 1990)

\begin{abstract}
Accelerated natural lactic fermentation of mixed sorghum-cowpea (Formula 1) and sorghum-milkpowder (Formula 2) infant food formulas was achieved by repetitive ( 60 fermentation cycles of $24 \mathrm{~h}$ each) use of the previous batch as an inoculum at a rate of $10 \%(w / w)$ and resulted in a gradual establishment of mixed populations of lactic acid bacteria and yeasts. In Formula 1, early fermentation stages (fermentation cycles 1-4) were dominated by Leuconosioc and Lactococcus spp. which caused conditions inhibitive to yeasts. Probably due to micronutnent deficiencies, the former lactic acid bacteria were succeeded by a combination of Lactobacillus plantarum and Candida spp. achieving pH values 4.2-4.3. In Formula 2 , Lactobacillus acidophilus, Lactococcus lacus and Lactobacillus brevis consistently achieved $\mathrm{pH}$ 3.7-3.8. thereby allowing only a minority of yeasts. mainly Candida and Trichosporon spp. None of the isolated yeasts exhibited 'killer'-actıvity.
\end{abstract}

Key words: Infant food: Weaning food: Lactıc fermentation; Succession; Lactic acid bacteria; Yeast: Killer activity

\section{Introduction}

In tropical regions. lack of refrigeration facilities at the household level enables rapid proliferation of microbial contaminants in foods. Especially with infant food like porridge which is often prepared only once or twice daily for use during the whole day, the growth of e.g pathogenic bacteria may contribute to acute diarrhea, which is one of the predominant causes of childhood mortality (Snyder and Merson. 1982).

Lactic fermentation of foods of plant or animal origin is a widely accepted method of preservation which may as well impart desirable sensory and nutritional properties to the fermented product (Cooke et al., 1987). Whereas lactic fermentation in e.g. sauerkraut may be achieved by allowing a lengthy succession of naturally occurring microorganisms, the use of pure culture starters under aseptic conditions has found wide application in industrial-scale fermentations. However, the use of

Correspondence address: M.J.R. Nout. Department of Food Science, Agricultural University, Bomenweg 2, 6703 HD Wageningen, The Netherlands. 
natural starters such as applied in e.g. the sourdough process (Sugihara. 1985). appears more appropriate in the household and small-scale industrial processes.

Accelerated natural lactic fermentation can be achieved by repetitive use of $5-10 \%(w / w)$ of a previously fermented batch as a starter. It was shown earlier (Nout et al., 1989a) that mixtures of cereals and pulses fermented in this way have a strong antimicrobial effect towards a range of pathogenic bacteria.

During the building-up of sourdough starters (Nout and Creemers-Molenaar. 1986) and accelerated natural lactic fermentation of soya beans for tempe manufacture (Nout et al., 1987b), it was observed that the process of acidification stabilised already after 3-5 consecutive fermentation cycles. However. it took much longer (30, resp. 60 cycles) for natural selection to result in a rather stable microbiological composition.

The present investigation was carried out to identify the predominant microorganisms involved in the accelerated natural lactic fermentation of two sorghumbased infant food formulas, and the time-scale of the natural selection involved.

\section{Materials and Methods}

\section{Ingredients}

Ingredients included white sorghum (Sorghum bicolor ssp. caffrorum), red cowpeas (Vigna unguiculata), and low-fat medium-heated spray-dried milk powder (CCF, Leeuwarden. The Netherlands).

\section{Preparation of formulas}

Sorghum and cowpeas were cleaned dry and ground to whole-grain meals using a toothed disc mill (Condux type LV $15 \mathrm{M}$, Condux-Werk, Wolfgang bei Hanau. F.R.G.). Formulas were designed to contain approx $13 \%(\mathrm{w} / \mathrm{w})$ of metabolisable protein (Nout et al., 1989b). Formula 1 consisted per $1000 \mathrm{~g}$ of $830 \mathrm{~g}$ of sorghum meal and $170 \mathrm{~g}$ of cowpea meal. Formula 2 consisted per $1000 \mathrm{~g}$ of $920 \mathrm{~g}$ of sorghum meal and $80 \mathrm{~g}$ of milk powder.

\section{Accelerated natural lactic fermentation of formulas}

The principle of starting a stable accelerated natural lactic fermentation was described earlier (Nout et al., 1987b, 1989b). For the first fermentation cycle, a mixture of $40 \mathrm{~g}$ dry formula and $60 \mathrm{ml}$ tapwater was incubated in a $450-\mathrm{ml}$ screw-capped glass jar at $30^{\circ} \mathrm{C}$ for $24 \mathrm{~h}$. Further fermentation cycles also lasted 24 $\mathrm{h}$ at $30^{\circ} \mathrm{C}$ and the mixture consisted of $36 \mathrm{~g}$ dry formula, $54 \mathrm{ml}$ tapwater and $10 \mathrm{~g}$ of the previous fermentation.

\section{Measurement of $\mathrm{pH}$ and titratable acıdity}

Sampling and determinations were as described earlier (Nout et al., 1989a).

\section{Microbiological analysis}

Enterobacteriaceae were enumerated in pour-plates of Violet Red Bile Glucose (VRBG, Oxoid CM 485) medium with overlay after incubation at $37^{\circ} \mathrm{C}$ for $24 \mathrm{~h}$. 
Enterobacteriaceae were isolated on VRBG $\left(37^{\circ} \mathrm{C} .24 \mathrm{~h}\right)$. purified on Plate Count Agar (PCA, Oxoid CM 325) $\left(37^{\circ} \mathrm{C}, 24 \mathrm{~h}\right)$ and identified using the 'API $20 \mathrm{E}$ ' system (API System SA, Montalieu Vercieu. France).

Lactic acid bacteria were enumerated in pour-plates of de Man, Rogosa and Sharpe (MRS) medium (Merck No. 10661, Darmstadt, F.R.G.) to which $12 \mathrm{~g}$ agar and $1 \mathrm{~g}$ natamycin ('Delvocid', Gist-brocades. Delft. The Netherlands) were added per litre, with overlay, after incubation at $30^{\circ} \mathrm{C}$ for $3-5$ days; they were isolated and purified on MRS agar and maintained in MRS broth. Initial confirmation and grouping of lactic acid bacteria was based on Gram stain, catalase activity, growth at $15^{\circ} \mathrm{C}$ and $45^{\circ} \mathrm{C}$ in MRS medium, gas from glucose and fermentation of lactose. sucrose, arabinose, sorbitol, cellobiose, fructose and mannitol added to glucose-free MRS medium. The square root of the number of colonies on the MRS agar plate dilution chosen for enumerations were isolated, purified and further characterised using the 'API 50 CHL' system (API System SA, Montalieu Vercieu, France).

Enumeration of yeasts and filamentous fungi was in pour-plates of Oxytetracyclin Glucose Yeast Extract (OGYE) agar, incubated at $25^{\circ} \mathrm{C}$ for 5 days (Nout et al., 1987a). Isolations and purifications were carried out on Glucose Yeast Extract agar (Oxoid, CM545).

Filamentous fungi were identified after 10 days incubation at $25^{\circ} \mathrm{C}$ on Malt Extract agar (MEA, Oxoid CM 59) and Czapek Dox agar (Oxoid CM 97) according to Samson and Van Reenen-Hoekstra (1988). Yeasts were grouped according to their morphology, and ability to sporulate on either V-8 agar. MEA or Yeast-MEA (malt extract $10 \mathrm{~g}$, yeast extract $4 \mathrm{~g}$, glucose $4 \mathrm{~g}$, agar $15 \mathrm{~g}$, distilled water to 1000 $\mathrm{ml}, \mathrm{pH} \pm 7.3$ ), their ability to ferment glucose, grow at $37^{\circ} \mathrm{C}$ and utilise $\mathrm{KNO}_{3}$ or lysine as sole source of nitrogen (Campbell and Duffus, 1988). Further characterisation was carried out using the 'ATB $32 C^{C}$ 'system (API System SA. Montalieu Vercieu, France).

All isolated yeast pure cultures were tested for 'killer' activity according to Somers and Bevan (1969) on YPG-K agar containing $10 \mathrm{~g}$ yeast extract (Oxoid), 10 g peptone (Difco), $20 \mathrm{~g}$ glucose, $20 \mathrm{~g}$ agar. $110 \mathrm{ml}$ of a $1 \mathrm{M} \mathrm{Na} 2 \mathrm{HPO}_{4}-\mathrm{Na}_{3}$ citrate buffer of $\mathrm{pH} 4$ and $0.03 \mathrm{~g}$ Methylene Blue per litre of medium. Reference strains included 'sensitive' strain FL100, 'killer-K1' strain K12 and 'killer-K2' strain Levuline killer K2. and were obtained from the Institut d'Oenologie, Université de Bordeaux II. France.

\section{Results}

The $\mathrm{pH}$ and counts of lactic acid bacteria, yeasts and Enterobacteriaceae at the end of consecutive fermentation cycles are presented in Table I.

In Formula 1, the final $\mathrm{pH}$ reached a minimum of 3.7 after 3 cycles whereupon it gradually stabilised at 4.2 . Throughout the experiments, the number of lactic acid bacteria remained very high ( $\log \mathrm{cfu} / \mathrm{g} 9.5-9.7)$. At first, yeast counts were quite low but they increased after some cycles to $\log \mathrm{cfu} / \mathrm{g} 6-7$. This coincided with a 
TABLE I

Acidification and content of lactic acid bactena. yeasts and Enterobactenaceae during accelerated natural lactic fermentation of sorghum-based infant food formulas

\begin{tabular}{|c|c|c|c|c|c|c|c|c|}
\hline \multirow{2}{*}{$\begin{array}{l}\text { Number of } \\
\text { completed } \\
\text { fermentation } \\
\text { cycles ( } 24 \text { h each) }\end{array}$} & \multicolumn{2}{|c|}{$\begin{array}{l}\text { pH of fermented } \\
\text { product }\end{array}$} & \multicolumn{2}{|c|}{$\begin{array}{l}\text { Lactic acid bactena } \\
(\log \mathrm{cfu} / \mathrm{g})\end{array}$} & \multicolumn{2}{|c|}{$\begin{array}{l}\text { Yeasts } \\
(\log c f u / g)\end{array}$} & \multicolumn{2}{|c|}{$\begin{array}{l}\text { Enterobacteriaceae } \\
(\log \mathrm{cfu} / \mathrm{g})\end{array}$} \\
\hline & Form. $1^{a}$ & Form. 2 & Form. 1 & Form. 2 & Form. 1 & Form. 2 & Form. 1 & Form. 2 \\
\hline 0 (start) & 6.0 & 6.3 & 2.8 & 2.2 & 3.6 & 3.0 & 2.5 & 4.6 \\
\hline 1 & 4.5 & 4.5 & 9.5 & 9.6 & 3.7 & 4.2 & 8.2 & $<1.7$ \\
\hline 2 & 3.9 & 4.2 & 9.7 & 9.8 & 2.7 & 2.1 & $<1.7$ & $<17$ \\
\hline 3 & 3.7 & 3.9 & 9.7 & 9.6 & 3.0 & 2.2 & $<1.7$ & $<1.7$ \\
\hline 4 & 3.9 & 3.8 & 9.5 & 9.8 & 4.5 & 2.1 & $<1.7$ & $<1.7$ \\
\hline 13 & 4.1 & 3.8 & 9.6 & 9.6 & 7.1 & 2.5 & $<1.7$ & $<1.7$ \\
\hline 27 & 4.3 & 3.8 & 9.6 & 9.8 & 6.4 & 2.5 & $<1.7$ & $<1.7$ \\
\hline 60 & 4.2 & 3.7 & 9.5 & 9.7 & 6.7 & 3.8 & $<1.7$ & $<1.7$ \\
\hline
\end{tabular}

${ }^{a}$ Form. 1: $830 \mathrm{~g}$ sorghum meal $+170 \mathrm{~g}$ cowpea meal; Form. $2 \cdot 920 \mathrm{~g}$ sorghum meal $+80 \mathrm{~g}$ non-fat milkpowder.

\section{TABLE II}

Lactic acid bactena isolated dunng accelerated natural lactic fermentation of sorghum-based infant food formulas

\begin{tabular}{|c|c|c|}
\hline \multirow{2}{*}{$\begin{array}{l}\text { Number of completed } \\
\text { fermentation cycles } \\
\text { ( } 24 \mathrm{~h} \text { each) }\end{array}$} & Formula 1 & Formula 2 \\
\hline & $n$ "Species & $\overline{n \text { Species }}$ \\
\hline 0 (start) & 4 Leuconostoc dexiranicum & 3 Leuconostoc dextranicum \\
\hline 1 & 6 Lactobacillus plantarum & 7 Leuconostoc dextranicum \\
\hline \multirow[t]{4}{*}{2} & 5 Leuconostoc dextranicum & 10 Lactobacillus acidophtlus 2 \\
\hline & 6 Leuconostoc lactis & 5 Leuconostoc dextranicum \\
\hline & 2 Lactococcus lactis & \\
\hline & 2 Laciobacillus acidophilus 2 & \\
\hline \multirow[t]{2}{*}{3} & 9 Leuconosioc dexiranicum & 8 Leuconostoc dexiranicum \\
\hline & 5 Laciobacillus acidophilus 2 & 4 Laciobacillus acidophilus 2 \\
\hline \multirow[t]{3}{*}{4} & 10 Lactococcus lachs & 8 Leuconostoc dexiranicum \\
\hline & 4 Leuconosioc dextranicum & 5 Lactobacillus acidophilus 2 \\
\hline & & 3 Lactobacillus brevts 3 \\
\hline 13 & 11 Leuconosioc dexiranicum & 9 Lactobacillus acidophilus 1 \\
\hline \multirow[t]{2}{*}{27} & 12 Laciobacillus plantarum & 9 Lactobacillus actdophtlus 1 \\
\hline & & 5 Lactococcus lactis \\
\hline \multirow[t]{2}{*}{60} & 12 Lactobacillus plantarum & 11 Lactobacillus acidophilus 1 \\
\hline & & 4 Lactobacillus brevis 3 \\
\hline
\end{tabular}

a number of isolates. 


\section{TABLE III}

Yeasts isolated dunng accelerated natural lactic fermentation of sorghum-based infant food formulas

\begin{tabular}{|c|c|c|}
\hline \multirow{2}{*}{$\begin{array}{l}\text { Number of completed } \\
\text { fermentation cycles } \\
\text { ( } 24 \mathrm{~h} \text { each) }\end{array}$} & Formula 1 & Formula 2 \\
\hline & $n$ 'Species & $n$ Species \\
\hline \multirow[t]{4}{*}{0 (start) } & 3 Rhodotorula glut!nis & 6 Candida curvata \\
\hline & 3 Rhodotorula rubra & 7 Candida curvata \\
\hline & 4 Cryptococcus uniguttulatus & \\
\hline & 3 Cryprococcus albidus & \\
\hline \multirow[t]{2}{*}{1} & 12 Candida famala & 8 Candida curvata \\
\hline & 4 Rhodotorula rubra & 4 Candida curvata \\
\hline \multirow[t]{2}{*}{2} & 9 Candida famata & 11 Candida curvata \\
\hline & 3 Rhodotorula rubra & \\
\hline 3 & 8 Candida famata & \\
\hline 4 & & 5 Candida guilhermondi \\
\hline 13 & 15 Candida famata & \\
\hline 27 & 9 Candida famata & 8 Candida famata \\
\hline \multirow[t]{2}{*}{60} & 9 Candida famata & 5 Candida famata \\
\hline & & 4 Trichosporon beigelu \\
\hline
\end{tabular}

a $n$, number of isolates.

slight increase of $\mathrm{pH}$. Enterobacteriaceae were present during the first cycle after which they were eliminated.

In Formula 2, the final pH stabilised at 3.7-3.8. Whereas the counts of lactic acid bacteria and Enterobacteriaceae followed the same trend as in Formula 1, the yeast counts remained significantly lower with a slight increase after 27-60 cycles to $\log \mathrm{cfu} / \mathrm{g}$ 3.8. The $\mathrm{pH}$ of the fermented product remained constant. The Enterobacteriaceae isolated during the first fermentation cycle of Formula 1 included in order of decreasing occurrence: Enterobacter agglomerans, Citrobacter freundii, Enterobacter sakazaki, Klebsiella ozaenae and Enterobacter cloacae. From Formula 2, Enterobacter sakazaki, Enterobacter agglomerans and Citrobacter freundii were isolated during the first fermentation cycle.

In the raw materials and during the first fermentation cycle, filamentous fungi included Aspergillus candidus, Aspergillus flavus, Aspergillus fumigatus, Aspergillus niger and some Penicillium spp. During later stages, filamentous fungi could not be detected. The dominating groups of lactic acid bacteria during consecutive cycles of the fermentation of Formulas 1 and 2 are presented in Table II.

Similarly, Table III presents the yeasts, which were isolated during progressive cycles of fermenting Formulas 1 and 2. None of the isolated yeasts formed ascospores after 2 and 4 weeks incubation at $25^{\circ} \mathrm{C}$, and none were of the 'killer' type. Towards the end of the experiment i.e. cycle 60 , Formula 1 was dominated by Lactobacillus plantarum and Candida famata. Formula 2 contained Lactobacillus acidophilus, Lactobacillus brevis, Candida famata and Trichosporon beigelii. 


\section{Discussion}

The Enterobacteriaceae occurring during the first fermentation cycle are common on plant material and were found also in natural fermentation of e.g. soya beans (Mulyowidarso et al., 1989) and early stages of the sourdough fermentation (Lönner et al., 1986). Their disappearance in the following cycles with $\mathrm{pH}<4.5$ is in accordance with the death kinetics of Enterobacteriaceae in similarly fermented material (Nout et al., 1989a).

Notwithstanding the 'non-sterile' character of the fermentation technique, naturally occurring filamentous fungi appear to be unable to compete in the combination of acidity and poor access of atmospheric oxygen prevailing in the fermenting dough-like mass. This implies that there is no risk that mycotoxins will be formed during the fermentation process. However, the risk of raw materials being contaminated with mycotoxins shall be mentioned.

From the results in Tables II and III it can be observed that the choice of raw materials influences the long-term succession and dominance of lactic acid bacteria and yeasts. In Formula 1, fermentation cycles 1-13 were dominated by Leuconostoc dextranicum, Lactobacillus acidophilus groups 1 and 2 and Lactococcus lactis, all having a limited assimilative spectrum (able to ferment 10-14 out of 48 tested sources of carbon) but achieving low final $\mathrm{pH}$ values. Depending on the presence of acetic acid (Nout et al., 1987b), the minimum $\mathrm{pH}$ allowing yeast growth in sourdoughs was 4.0 except for Candida krusel which still grew at pH 3.6 (Spicher and Schröder, 1980). The resulting low numbers of yeasts may have caused a deficiency of growth factors required for the lactic acid bacteria. This was shown earlier with lactic acid bacteria from sourdoughs which required vitamins (Spicher and Schröder, 1979a) and varying numbers of amino acids (Spicher and Schröder. $1979 \mathrm{~b}$ ), to be supplied either by fresh yeast extract (Kline and Sugihara, 1971), a peptide (Sugihara, 1985) or log cfu/g 6-7 live yeast cells (Spicher et al., 1981). As a result of such deficiencies, the lactic acid bacteria would produce less acid and in turn allow a significant increase of yeast counts after cycle 4. As long as the pH remains favourable (i.e. $\mathrm{pH}>4$ ) the yeasts can maintain their growth due to their broad assimilative spectrum (Candida famata being able to assimilate 21 out of 30 tested sources of carbon). An equilibrium is reached with Lactobacillus plantarum of broad assimilative spectrum ( 22 out of 48 carbon sources) which acidify to $\mathrm{pH}$ levels (4.2-4.3) at which Candida famata grows well.

In Formula 2, the presence of milk solids may satisfy the long-term nutritional requirements of lactic acid bacteria. Consequently. acid-tolerant lactose fermenting Lactobacillus acidophilus but also the lactose non-fermenting Lactobacillus brevis can co-exist with a minority of both lactose fermenting Trichosporon beigelii and lactose non-fermenting Candida famata. Candida famata isolated from maize silage was able to assimilate lactate. particularly under aerobic conditions (Middelhoven and Van Baalen, 1988). Trichosporon betgellı can also assimilate lactate; it is therefore important to maintain anaerobiosis.

Since no 'killer' yeasts were found among the dominating species, the 'killer' phenomenon does not appear to be involved in their succession. On the other hand, 
it is interesting to note that Rhodotorula glutinis, Rhodotorula rubra, Cryptococcus uniguttulatus and Cryptococcus albidus which were present during the first fermentation cycle of Formula 1 were not resistant against 100 ppm cycloheximide. In later stages, only cycloheximide-resistant yeasts were isolated. This has also been found in equilibrated populations of yeasts and lactic acid bacteria in sourdoughs (Nout and Creemers-Molenaar, 1986).

In conclusion, it is suggested that the extent of acidification of long-term accelerated natural lactic fermentations of cereal-based mixtures will, inter alia, depend on the availability of micronutrients for lactic acid bacteria. If the latter are deficient in the raw material to be fermented, they will have to be supplied by yeast cells, and consequently an equilibrium situation will be established with final $\mathrm{pH}$ values and acetic acid concentrations enabling adequate yeast growth. Additional experiments with pure and mixed cultures in micronutrient deficient fermentations are needed to confirm this hypothesis.

\section{Acknowledgements}

The author gratefully acknowledges the collaboration of C.W.C. van Muijen and H.M. Bouwmeester, Department of Food Science, Agricultural University, Wageningen.

\section{References}

Campbell, I. and Duffus, J.H. (1988) Yeast. A Practical Approach. IRL Press. Eynsham. Oxford.

Cooke, R.D., Twiddy, D.R. and Reilly. P.J.A. (1987) Lactic-acid fermentation as a low-cost means of food preservation in tropical countries. FEMS Microbiology Rev. 46, 369-379.

Kline, L. and Sugihara. T.F. (1971) Microorganisms of the San Francisco sour dough bread process. II. Isolation and characterization of undescribed bacterial species responsıble for souring activity. Appl Microbiol. 21, 459-465.

Lönner. C., Welander, T., Molin, N. and Dostálek, M. (1986) The mucroflora in a sour dough started spontaneously on typical Swedish rye meal. Food Microbiol. 3. 3-12.

Middelhoven. W.J. and Van Baalen, A.H.M. (1988) Development of the yeast flora of whole-crop maize during ensiling and during subsequent aerobiosis. J. Sci. Food Agric. 42, 199-207.

Mulyowndarso, R.K., Fleet, G.H. and Buckle, K.A. (1989) The microbial ecology of soybean soakıng for tempe production. Int. Food Microbiol. 8, 35-46.

Nout, M.J.R. and Creemers-Molenaar, T. (1986) Microbiological properties of some wheatmeal sourdough starters. Chemie Mikrobiol. Technol. Lebensmitt. 10, 162-167.

Nout, M.J.R., Beernink, G. and Bonants-Van Laarhoven, T.M.G. (1987a) Growth of Bacillus cereus in soyabean tempeh. Int. J. Food Microbiol. 4, 293-301.

Nout, M.J.R., De Dreu, M.A., Zuurbier, A.M. and Bonants-Van Laarhoven, T.M.G. (1987b) Ecology of controlled soyabean acidification for tempe manufacture. Food Microbiol. 4, 165-172.

Nout, M.J.R., Rombouts. F.M. and Havelaar, A. (1989a) Effect of accelerated natural lactic fermentation of infant food ingredients on some pathogenic microorganisms. Int. J. Food Microbiol. 8, 351-361.

Nout, M.J.R., Rombouts, F.M. and Hautvast, G.J. (1989b) Accelerated natural lactic fermentation of infant food formulations. Food and Nutrition Bulletin U.N.U. United Nations University 11.65-73.

Samson. R.A. and Van Reenen-Hoekstra. E.S. (1988) Introduction to food-borne fungi. Centraalbureau voor Schimmelcultures, Baarn and Delft. The Netherlands. ISBN 90-70351-16-1. 
Snyder, J.D. and Merson, M.H. (1982) The magnitude of the global problem of acute diarrhoeal disease: a review of active surveillance data. Bull. W.H.O. 60, 605-613

Somers. J.M. and Bevan. E.A (1969) The inheritance of the killer character in yeast. Genetic Res. 13. $71-83$.

Spıcher. G. and Schröder, R. (1979a) Die Mikroflora des Sauerteıges V. Das Vitamınbedurfnıs der in "Reınzuchısauern" und in Sauerteıgen anzutreffenden stäbchenförmugen Milchsäurebakterien (Genus Lactobacillus Beyennck). Zeitschr. Lebensm. Unters. Forsch. 168, 188-192.

Spıcher, G. and Schröder, R. (1979b) Die Mikroflora des Sauerteıges. VI. Das Amnosaurebedurfnıs der in "Reinzuchtsauern" und in Sauerteigen anzutreffenden stäbchenformugen Milchsäurebaktenen (Genus Lactobacıllus Beijerinck). Zeıtschr. Lebensm. Unters. Forsch. 168. 397-401.

Spıcher. G. and Schröder. R. (1980) Die Mikroflora des Sauerteıges. VIII. Die Faktoren des Wachstums der Im "Reinzuchtsauer" auftretenden Hefen. Zettschr. Lebensm. Unters. Forsch. 170. 119-123

Spıcher. G., Rabe, E., Sommer, R, and Stephan, H. (1981) Die Mikroflora des Sauerteiges. XIV. Über das Verhalten homofermentatıver Sauerteigbaktenen und Hefen bet gemeinsamer Kultur. Zeıtschr. Lebensm. Unters. Forsch. 173, 291-296.

Sugihara, T.F. (1985) Microbıology of breadmaking. In: B.J.B. Wood (Ed.), Microbıology of Fermented Foods. Vol. 1. Elsevier, Barking, Essex. pp. 249-261. 